\title{
Visual Adaptation: From Comics to Superhero Creation of Wayang
}

\author{
Taufiq Akbar a,1,*, Dendi Pratama ${ }^{\mathrm{a}, 2}$, Sarwanto ${ }^{\mathrm{b}, 3}$, Sunardi b,4 \\ ${ }^{\text {a }}$ Universitas Indraprasta PGRI, Universitas Indraprasta PGRI \\ ${ }^{\mathrm{b}}$ Indonesia Institute of the Arts Surakarta, Jl. Ki Hajar Dewantara No.19, Kentingan, Jebres, Surakarta - Jawa Tengah \\ ${ }^{1}$ grapickology.ta@gmail.com*; ${ }^{2}$ dendi.pratama@unindra.ac.id; ${ }^{3}$ sarwantomardisaputra@yahoo.com; ${ }^{4}$ gunowijoyo@gmail.com \\ * Corresponding Author
}

Received 9 Jul 2020; accepted 4 Sept 2020; published 1 Apr 2021

\section{ABSTRACT}

This article reveals the concept of unifying wayang as a traditional culture with comics and films as a product of the modern culture that has given birth to new wayang creations with sources adapted from "Avenger" superhero characters. Wayang Avenger is made based on the aesthetics of wayang kulit adaptively but maintains craftsmanship in wayang kulit. What is evident from the wayang kulit is the traditional inlay and attributes of the purwa leather puppets. Inlay and various attributes in wayang kulit purwa are an adaptation effort to achieve a new aesthetic that is hope. This article seeks to find and provide an interpretive descriptive explanation of the visual adaptations used by wayang avenger's work, with Erwin Panofsky's iconographic approach supported by the theory of art structures and vehicle transfer. The presentation of the Avenger Creation Puppet is a form of a combination of traditional and modern culture. This development reflects the interplay between traditional heritage and contemporary cultural phenomena, ultimately resulting in aesthetic adaptations in wayang.

\section{KEYWORDS}

Wayang

Creative Wayang

Avenger

Visual Adaptation

Comics

This is an openaccess article under the CC-BY-SA license

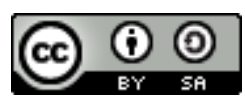

\section{Introduction}

The development of community culture is currently heading towards a modern society that has impacted traditional culture changes. Some people's views of life and attitudes have begun to shift, tend to be easy, fast, and instantaneous. The community seems to lack any confidence in the sublime meaning hidden behind the traditional symbols. Many cultural products from Javanese traditional arts have lost their symbolic power related to noble teachings. The loss of this symbolic power is because there is an assumption that traditional art products are complicated and mystical, so there is an assumption that wayang performances are outdated and not following modern styles or trends. Byard and Jones explain that most Javanese consider wayang kulit as the most important cultural form. Wayang is said to encompass all art forms, represent Javanese culture's soul, and teach philosophical and ethical values (Byard-Jones 2001, 43). The form is enjoyed as a means of entertainment and, more importantly, represents values, norms, and beliefs (Ghani and Ishak 2011, 2).

Wayang is a great masterpiece, where the puppet becomes a symbol of a bridge that connects different cultures. The definition of culture is how a group of people develops, reproduces, and redefines a frame of reference consisting of sharing knowledge, values, beliefs, social roles, and social institutions (Storey 1993, 33). In a scholarly article, the wayang's core tradition is the wayang purwa (original wayang), using stories from the ancient Indian epics, Ramayana, and the Mahabharata tale is by far the most popular. Another wayang "branch" traditions vary these elements, such as wayang madya, telling stories from medieval romances such as the Panji and Damarwulan cycles, accompanied by the gamelan pelog (Byard-Jones 2001). The pouring of conceptual elements in the wayang stories and characters harmonizes the cultural mix that is open to each other so that the puppets can develop along with the times. Even though they are very old, traditional, and classic, wayang kulit can survive the passage of time, adapting to the times' ideas and needs (Bangsa 2002).

Wayang kulit purwa performances today have developed both in form and function. This development results from the influence of customary heritage and its interaction with the outside 
world's phenomena, which ultimately results in adaptation to the environment and social structures (Soetarno dan Sarwanto 2010, 10). As a cultural product, we cannot separate wayang from society and its environment (Pratama 2015, 380). Therefore various types of wayang creations have emerged, each of which has creative ways, ideas/ideas, and objectives to preserve the art of wayang in this millennial era, such as the Avenger Creation Wayang.

Research on the Avenger Creation Puppet (Wayang Kreasi Avenger) is very important because it can reveal one of the adaptation concepts among the many ideas, which until now has no clear knowledge. The concept of adaptation is an essential problem in Avenger Creation Puppet (Wayang Kreasi Avenger) because the form and appearance, and attributes of the puppets adapt traditional Wayang (Purwa) even though the characters draw from the superhero fictional film "Avenger." This research aims to see the visual adaptation used to move the superhero characters in comics into wayang forms.

\section{Method}

This study seeks to find and provide an interpretive descriptive explanation of visual adaptation in creating wayang avenger. This study uses Erwin Panofsky's iconographic approach to support art structure theory and alih wahana (vehicle transfer) theory. The function of the two theories is to sharpen the results of identification, analysis, and interpretation. Collecting data in this study is direct or indirect to the source. Direct data collection is to obtain primary data, while indirect data collection is to get secondary data. As needed, to obtain accurate research data, this research requires data collection methods by (1) literature study, (2) field studies, (3) interviews. A literature study is a data search activity by tracking through various forms of documentation, books, articles in scientific journals, articles in magazines, seminar papers, and reports of previous research results. Field studies are observational activities that include direct observation and indirect observation. Direct observation is the observation and recording of various important things related to the object.

In this place, the creative Avenger Puppet Creation occurs so that the researcher who also acts as an observer is in the same place as the research object. In carrying out observations, researchers as observers try to take notes and take pictures directly of objects. Researchers see empirically the phenomena that are the target of the study. Indirect observation is implementing observations or notes that do not occur at the creative Avenger Wayang Kreasi creation event. The interview is to use an interview guideline instrument. Based on the guideline instrument, the researcher asked questions about several keys to competent informants. An interview is a question and answer activity between researchers and sources to complement data that does not appear in literature study and observation.

To discuss the visual adaptation of wayang avenger, the researchers studied it with iconography through three stages. The first is pre-iconographic descriptions, namely reading what appears to the object. The researcher's attention is to lines, colors, shapes, techniques, and materials representing natural objects. These natural objects are humans, animals, plants, and tools. The second is iconographic analysis, which interprets conventional secondary meanings based on images, stories or literature studies, and allegories/symbols to identify the work's themes and concepts. The third is the iconological interpretation. The stage is an essential phase because it is related to the intrinsic meaning or content of a work of art. This stage requires synthetic intuitive skills to understand symbols. Intuition synthesis concerns personal psychology's essential tendencies and the artist's weltanschauung (view of life).

\section{Results and Discussion}

\subsection{The Wayang Creation of the Superhero "Avenger"}

Indonesian culture manifests a unified cultural family present as a woven culture that makes Indonesians feel present as Indonesians. Indonesian culture is a series of unity between local culture/traditions and culture that comes from outside. The most dominant feature and an image are because it departs from the same root, namely the Eastern style. Wayang is the result of Indonesian culture that has gone through several morphological stages. The community is still preserving it along with the times and the people who support it. The preservation of wayang kulit does not mean that its 
development has stopped but has become a pattern in creating new wayang creations that have also enriched the Indonesian puppets' specialties.

Wayang creations that have recently received attention from young people are Wayang Avenger. The puppet creator is Is Yuniarto. Wayang Avenger is based on and adapted from the superhero "Avenger" characters. Avenger was originally a comic character, which the creators later turned into an object of expression in the film. The Marvel Cinematic Universe (MCU) debuted with a movie called Iron Man in mid-2008. It became a series of financially successful blockbuster films. The film also has a narrative link, showcasing the origins and subsequent adventures of Marvel Studios superhero characters such as Thor, Iron Man, Captain America, and the superhero team The Avengers.

According to Koh, as of December 2013, the MCU is one of the highest-grossing film franchises with more than the US $\$ 5.6$ billion in tickets sold across its eight films (Koh 2014, 485). The MCU is a series of related superhero films in the format of television shows, video games (games), and, of course, the Marvel Studios comic book series. The MCU has attracted much critical attention because of its impact on the entertainment industry (Acu 2016, 196; Lavin 1998). The highest-grossing proves that the superhero-themed film genre that Marvel Studios carry has a very extraordinary fan base because there is a personal interest in the actors and actresses. However, for Marvel comics fans, this film can bring them to see the real reality in the movie, more than just two-dimensional images like in comics.
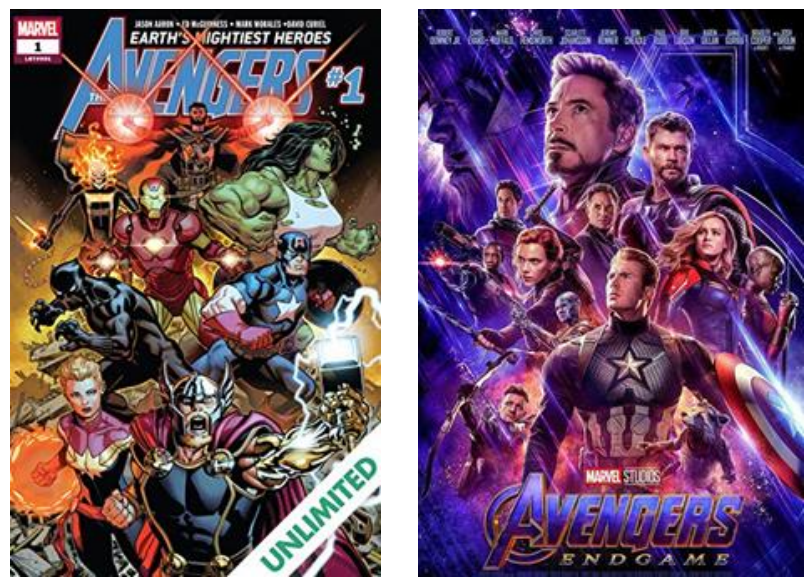

Fig. 1. Avenger Comic Cover \& Avenger Endgame Movie Poster (http://comixology.com, https://www.bbc.com/indonesia/majalah-48008865, downloaded by Akbar,1 May 2020)

The creators introduced the Avenger Wayang Design to the public through social media and turned it into a puppet in 2018. They got the opportunity from Walt Disney Indonesia to create the physical characters of shadow puppets from the Avengers characters they had previously drawn. At that time, Wayang Avenger focused on the characters Iron Man, Doctor Strange, and Nebula. They then gave the three puppets to Benedict Cumberbatch (who played Doctor Strange), Karen Gillan (who played Nebula), and Infinity War Joe Russo as the Avengers director. According to Is Yuniarto, traditional Indonesian wayang, which originates from the epic Mahabharata and Ramayana, is similar to the Avengers film in terms of its function as a medium for telling stories of heroism (Putra 2018).

\subsection{Visual Adaptation of Comics, Film, Wayang Creation Avenger}

The pre-iconographic description stage in the "avengers" wayang creation study explores the elaboration of textual and visual aspects by describing physical identities that appear factually in wayang works. At this stage, it requires an analysis of the art structure, which includes graphical elements and organizing visual elements in observation. This elaboration requires Edmund Burke Feldman's structural theory of art. According to Feldman, an art structure can be identified by focusing on lines, shapes, colors, textures, and light darkness which is part of the object/image form (Feldman 1991, 164). 
In terms of form, wayang avenger adapted it from the form of wayang kulit purwa. Determination of the proportion of the wayang avenger's height is approximately $40 \mathrm{~cm}$, starting from the top of the head to the legs using leather material. There is no high difference between the wayang putra (male wayang) and wayang putren (female puppet) characters, as is the case in the purwa wayang. Wayang avenger still maintains the art of craftsmanship in wayang kulit, namely the arrangement and possesses the traditional wayang attributes. There are adjustments to the superhero outfit with wayang clothing attributes to affect the inlay and the sunggingan (resulting from coloring activity after carving or staining activities in wayang making).

The recognizable inlay in the wayang purwa also appears in the avenger puppet. In both cases, several lines are visible from a distance. These lines fill each other in the puppet's form, starting from the head to the feet. The way to make these lines is by way of inlaying so that the parts with holes resulted from the inlay/carving are visible. Of course, the inlay on the wayang avenger is not as complicated as the inlay on the wayang purwa. Inlaid on wayang avenger only uses a few basic inlays of the attributes of the puppet purwa, such as sumping, praba, dodot, cloth folds/sembuliyan, and belts. The inlay on the wayang avenger, especially on these attributes, is like that of the Wayang purwa characters. An inlay modification comes from a combination inlay to adjust the fields that look empty, such as in the clothing section.

The inlay combination is perfect when combined with a good sunggingan. Sunarto, sunggingan is a traditional coloring with a color gradation technique or color grade, but each color's boundaries are visible (Sunarto 1997, 162). Sunggingan in wayang avenger, there is no level of color (gradation) as is usually the case in wayang purwa. The sunggingan in this wayang avenger adapts the colors that become the personal identity of the superhero. The color of the clothes seems to have an identity. Ironman superhero characters are identical with the colors gold, red, and silver. Doctor Strange's signature superhero character is dark blue and red. The dominant Nebula character is in light blue and purple. The overall application of the superhero costumes' colors is an attempt to shape the wayang avenger creations.

The next stage is iconographic analysis. This analysis stage interprets conventional secondary meanings based on images, stories or literature studies, and allegories/symbols to identify themes and concepts of the work (Panofsky 1955, 35). The making of Wayang Avenger is by adopting Avenger superhero characters from Marvel Comic. In recent years it has become very popular. They have captured the world community's attention because they are present in the big-screen film format by the Marvel Cinematic Universe (MCU). Since Thor's appearance in 2011, young people have been waiting for the MCU films. In 2012, the movie The Avenger first appeared by introducing a story about a team that saves the world from disaster.

The Avenger's story became more interesting when the second part of the film appeared, namely The Avenger: Age of Ultron (2015), The Avenger: Infinity War (2018). The story is getting more complex in the last series, namely The Avenger: End Game (2019). This superhero film is nothing more than a manifestation of a character-based commodity concept. Films starring big actors and those produced with big budgets have been massively promoted. Films can occupy a special space above the intertextual and paratextual hierarchy among individual superheroes (Koh 2014).

Wayang reflects tradition, expresses emotions and ambitions creatively through shadow communication reflected on a white screen called kelir (Ghani and Ishak 2012, 164). However, the demands of the times force the adaptation process to run without leaving tradition. The goal is that the puppet art does not disappear due to a lack of interest from the younger generation. As a cultural product, wayang must integrate its existence with society and its environment (Pratama 2015). Therefore, various types of creative wayang emerged, each of which has ways, creative ideas, and goals to preserve the art of wayang in this millennial era. Creative puppets are puppets that do not follow the standard of wayang kulit purwa in the form of stories and arrangements, either partially or completely (Pratama 2015). Long before creating this superhero avenger puppet, in 2001, Ki Enthus Susmono had also made wayang creations based on creating his characters from DC Comic superheroes, namely Batman and Superman. Ki Enthus has completed all the interstellar puppets, which he calls Planet Puppet. The puppets of Superman, Batman, Batwoman, and various Japanese manga characters allow him to compare these international icons with puppet "superheroes" such as Gathotkaca (Cohen 2007, 361). However, the wayang avenger is quite interesting because the forms 
tend to adopt the wayang purwa, adopting an inlaid system in the art of wayang craftsmanship. Meanwhile, the superhero puppets by Ki Enthus are more artistic creations that tend to have minimal inlay.
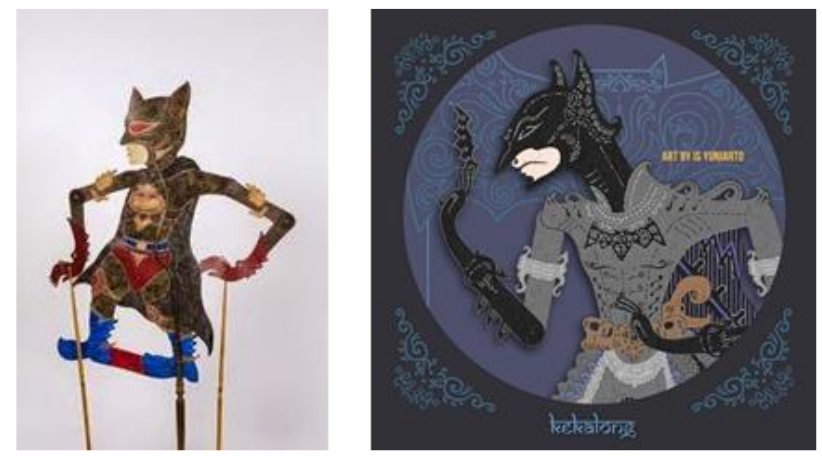

Fig. 2. Wayang Batman by Ki Enthus Susmono (Left) and Wayang Batman by Is Yuniarto (Right) (Wayang Batman by Ki Enthus Susmono - Collection of Nationaal Museum van Wereldculturen, inventory nr. TM-6330-24 (Boonstra 2019), Wayang Batman by Is Yuniarto, downloaded from Instagram @ is.yuniarto,1 May 2020)

The use of the word "creation" refers to the meaning of creativity (it can also be imaginary). That is, creation is the result of the human mind or intellect. To be creative means to produce something as a result of the thought of creating. As Clark Moustakis stated, creation is also closely related to creativity. Creativity is the experience of expressing and actualizing an individual's identity in an integrated form concerning oneself, with nature, and with others (Munandar 2002, 18). At this point, Is Yuniarto combines two cultural products into a visual composition that young people (teenagers) will easily accept. This combined cultural product carries the theme of heroism (superhero) as a reference for shaping the wayang's character and appearance without leaving the traditional Wayang (purwa) form.
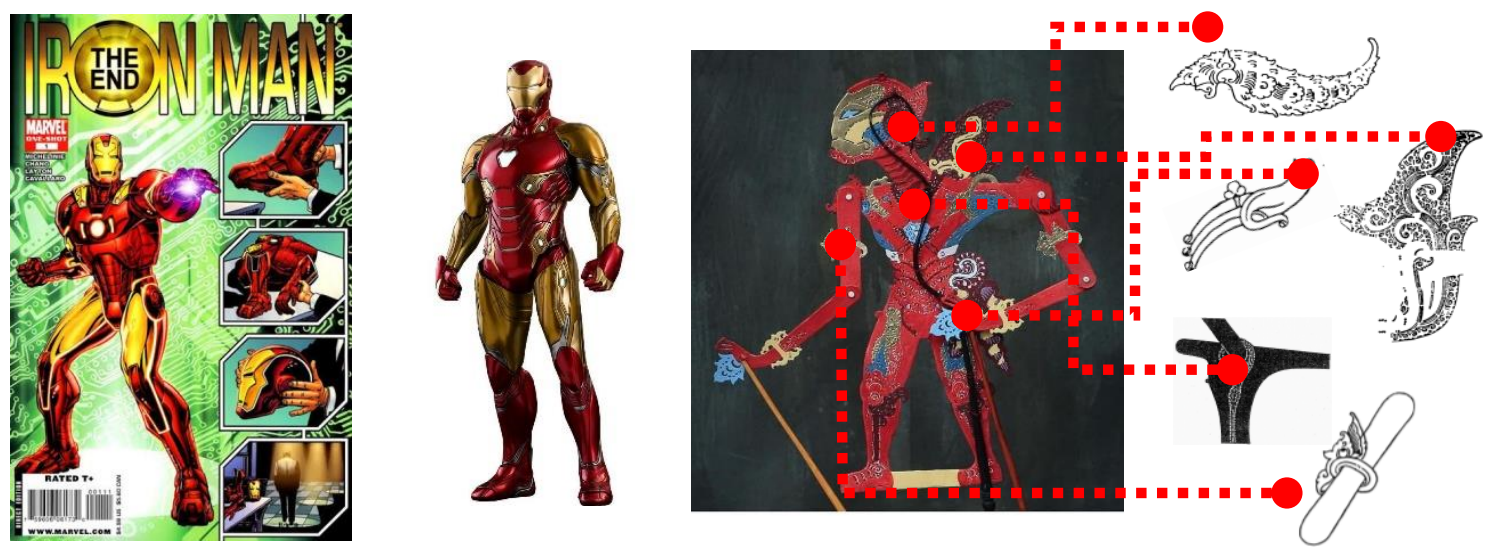

Fig. 3. Adapted Form from Comic to Become Wayang Avenger "Ironman"

(Modification: Akbar, 2019)

Making wayang avenger is by adapting from comics which later turned into film media. So, there was a process of changing from comics to wayang. Damono said alih wahana (transfer of vehicles) represents a form of adaptation that changes one type of art to another (Damono 2018, 12). Alih wahana (transfer of vehicles), in particular, is always a relationship or link between media. In the development of artistic activities, it is very common for one type of art to take another art as its source (Damono 2018).

In the concept of "transfer of the vehicle," there is a phenomenon of transformation, namely the depiction of forms that emphasize the attainment of character by moving (trans = moving) a shape or figure from one object to another created thing (Sony Kartika 2017, 39). Transformation also means 
changing into something. There is an assumption that transformation transforms from a form into a new figure as the final stage of a change process.
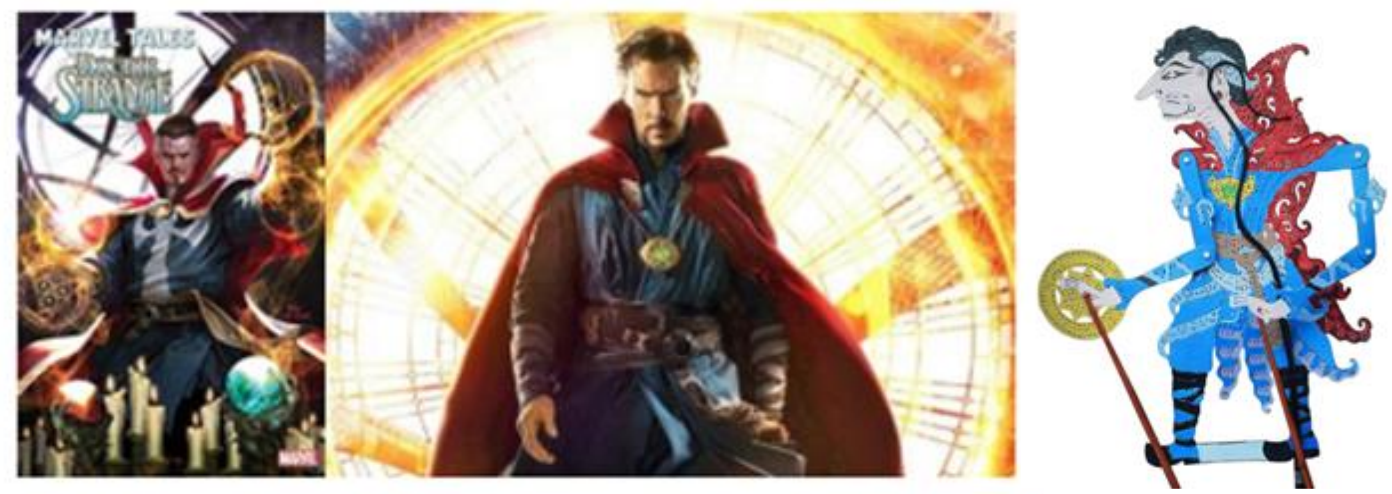

Fig. 4. Adapted Form from Comic to Become Wayang Avenger "Doctor Strange" (Modification: Akbar, 2019)

The visualization of the character's "wayang creations avenger" is like that in the film. According to Haryanto, the form of shadow puppets is generally a depiction of human shadows, which analytically we divided into three parts, namely: (1) the upper part, namely the neck and head, (2) the middle part, namely the body, (3) the limbs, namely feet and hands (Haryanto 1991, 31). Each of these parts always has an inlay and sunggingan pattern.

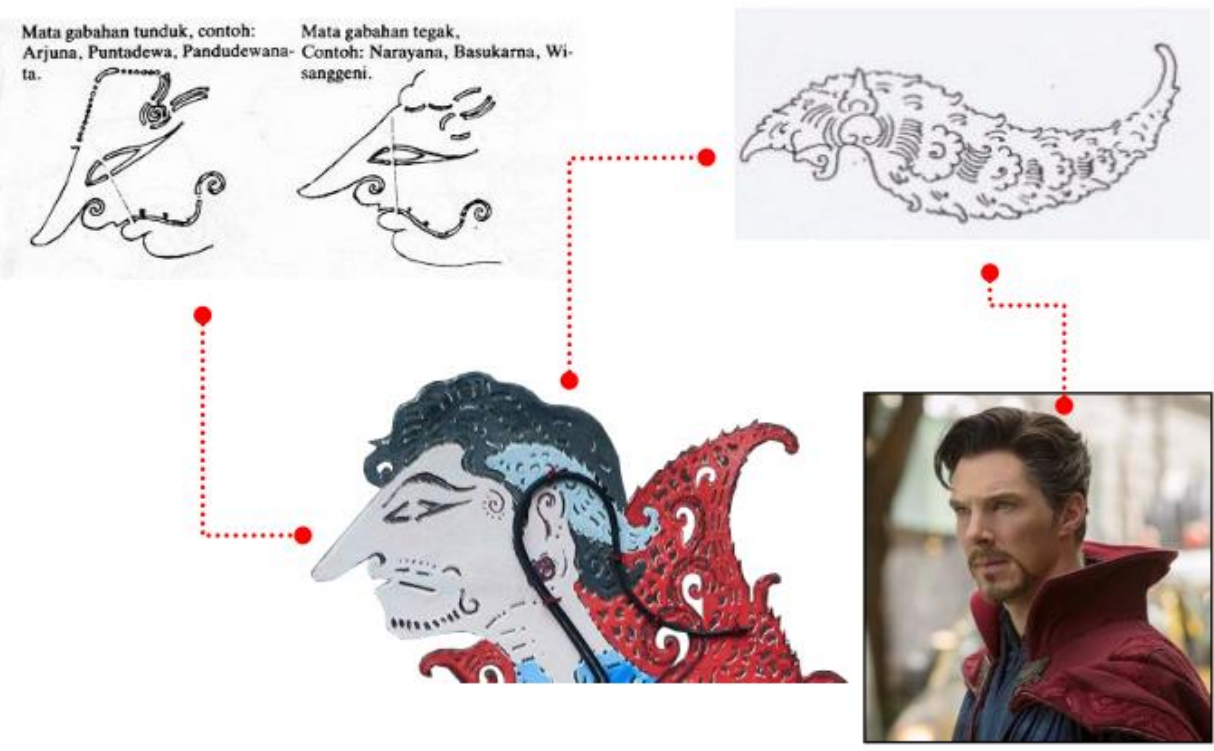

Fig. 5. Adaptation of Visual Elements on the Head (Modification: Akbar, 2019)

The puppet avenger's visualization of Doctor Strange's character, the top (neck head) is like a puppet alusan, has a sharp nose, gabahan eyes, and a flat face facing forward. The head does not use many accessories/attributes as in wayang purwa. However, the upper ear shows the attribute sumping (a type of jewelry worn on the ear) with an inlay like gold and a simple creation type inlay in place of Doctor Strange's grey hair actual character. 


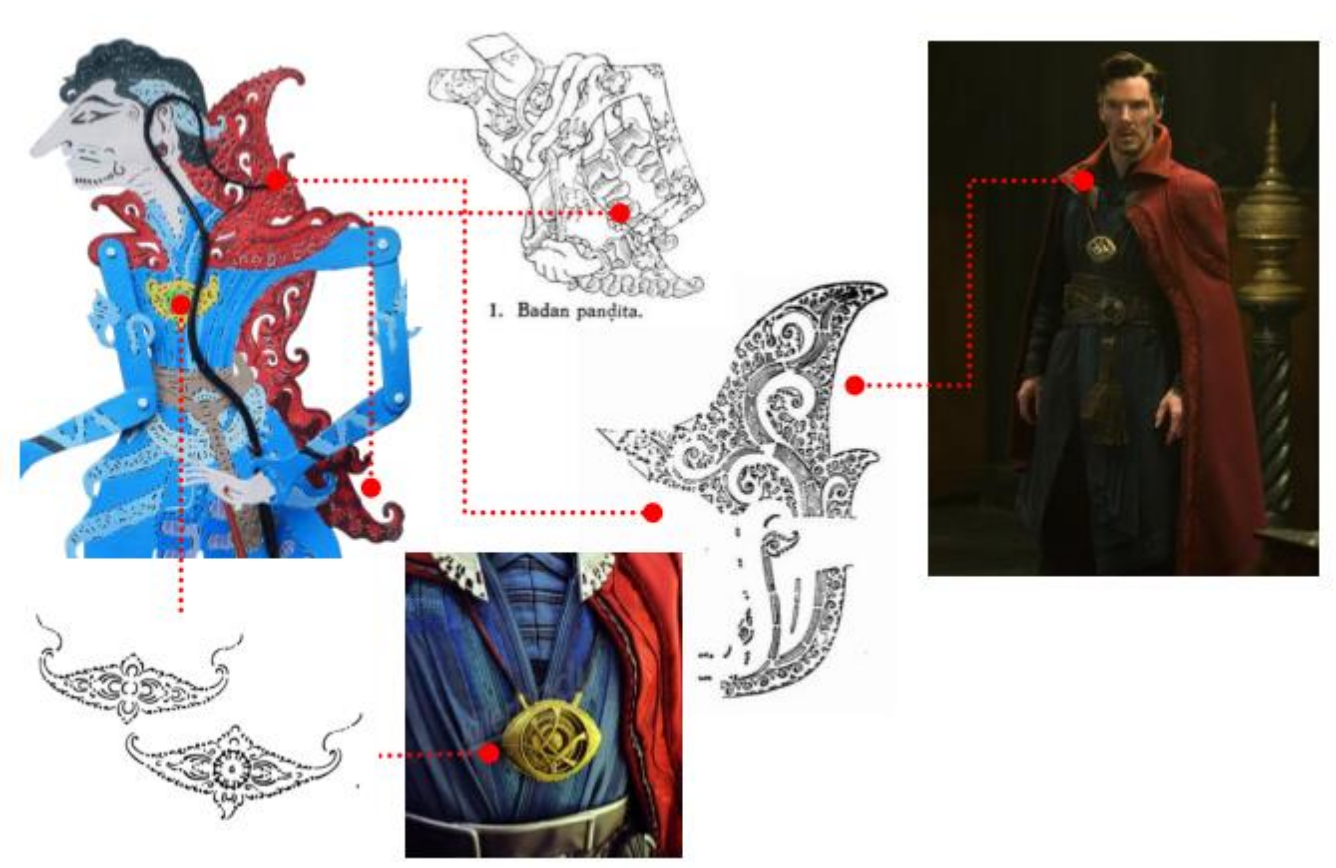

Fig. 6. Adaptation of Visual Elements on the Head (Modification: Akbar, 2019)

The depiction of the puppet avenger of Doctor Strange character in the middle (body) is wearing a complete distinctive outfit, namely Doctor Strange's iconic artifacts such as (1) the Cloak of Levitation robe, (2) the Eye of Agamotto necklace, and (3) the leather belt known as the Sash of Doctor Strange. This Cloak of Levitation robe has the main strength that it can cause every wearer to fly. This robe's advantage is that the wearer does not need to know much about witchcraft or use magic to operate it. In the wayang avenger, there are clothing modifications to this clothing attribute. Depiction of a cloak of levitation robe is that of a praba, but on the shoulders, it is like using a sampur. In Wayang Kulit Purwa clothing, praba is an oversized outfit for a puppet king or patih figure. For some characters in the wayang kulit purwa, praba often means a special outfit that can make the wearer fly.

Like the Cloak of Levitation, only a Sorcerer Supreme (a title for practicing magic and mysticism) can wear this robe. This robe also gives the user the ability to fly. Then, there is the Eye of Agamotto magic necklace, which has the power to manipulate time. The magic necklace's visualization in the wayang avenger is similar to kalung kebomangah in the purwa leather puppet. Furthermore, the depiction of the Sash of Doctor Strange belt is not like the shape of the belt in the wayang purwa, but rather like the Doctor Strange belt in comics or films.

Doctor Strange's puppet avenger's visualization, the limbs (hands and feet), uses the attribute "shoulder shelves" calumpringan model on the arms. In the film, Doctor Strange wears a watch on his left hand, but the watch does not appear as a bracelet in the wayang avenger. On Doctor Strange's right hand, there was an additional accessory, namely the magic power of the Eye of Agamotto, which was an ornate round like a mandala. At the foot, Doctor Strange appears to be wearing a model for the figures of rishis, priests, and gods. The fashion model seems from the body to the feet. The depiction of rishis figures, priests, and gods, in wayang purwa, often wears a robe with a single nine on the robe and shoes' edge. In the wayang avenger, Doctor Strange's depiction is also like a rishi or a priest's style. 


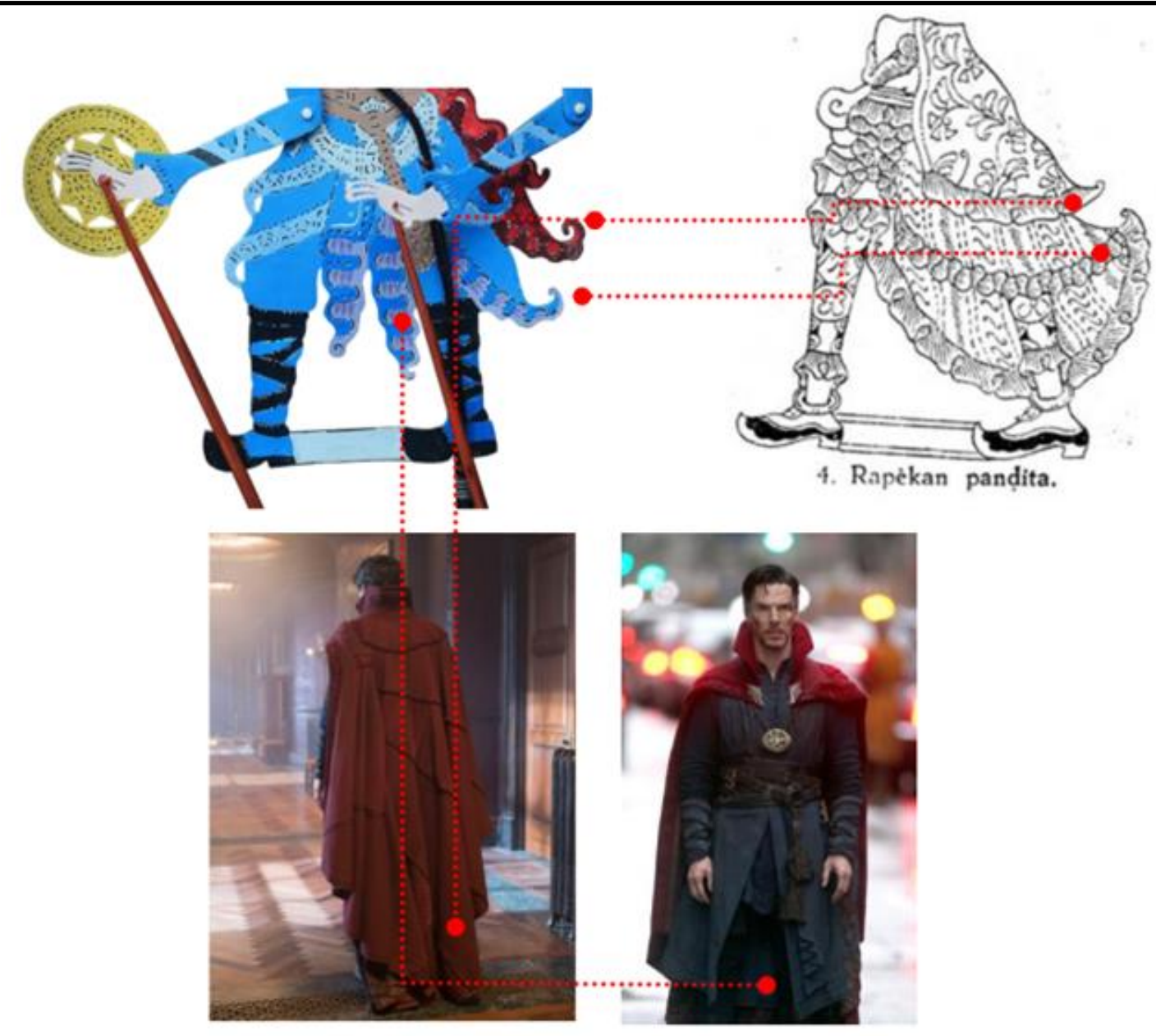

Fig. 7. Adaptation of Lower Visual Elements (Modification: Akbar, 2019)

\subsection{Avenger's Wayang Creations and Online Media}

The last stage in this research is the iconological interpretation stage. This stage is an essential stage, which departs from the corrected analysis at the iconographic analysis stage. This stage results from the intuition of the two stages' synthesis, revealing the meaning in Avenger's creations. Synthetic impulse is obtained based on psychological conditions or the view of the life of the observer of the work (Panofsky 1955).

Wayang Kreasi Avenger exists as a form of adaptation from traditional culture. In the past, wayang was a means or medium for spreading religion (da'wah). However, nowadays, wayang is a means of media that connects the millennial generation's insight gap and its own culture. When the current modernization went very strong, which was present through online media with all its sophistication, the media created a big change for enjoying wayang.

The picture on the following page shows a change in the new way young people recognize wayang. The problem is that only some people can enjoy traditional wayang performances, that is, people who may have been accustomed to wayang performances from generation to generation. Then, what about the current millennial generation, who are more used to newly formed cultures. The image below is a simulation of how young people enjoy the wayang. With the advancement of social media development on various platforms, human interaction can occur outside its normal limits. Initially, the presentation of a puppet show complete with gamelan accompaniment and all the supporting instruments usually took place in front of the screen. Now, enjoying wayang presentations does not have to be accompanied by gamelan and all complete supporting instruments but can also be enjoyed through social media. Social media becomes a "stage" to replace color. We can see the audience's 
enthusiasm in the number of "likes" and "comments" statements printed on each social media platform.

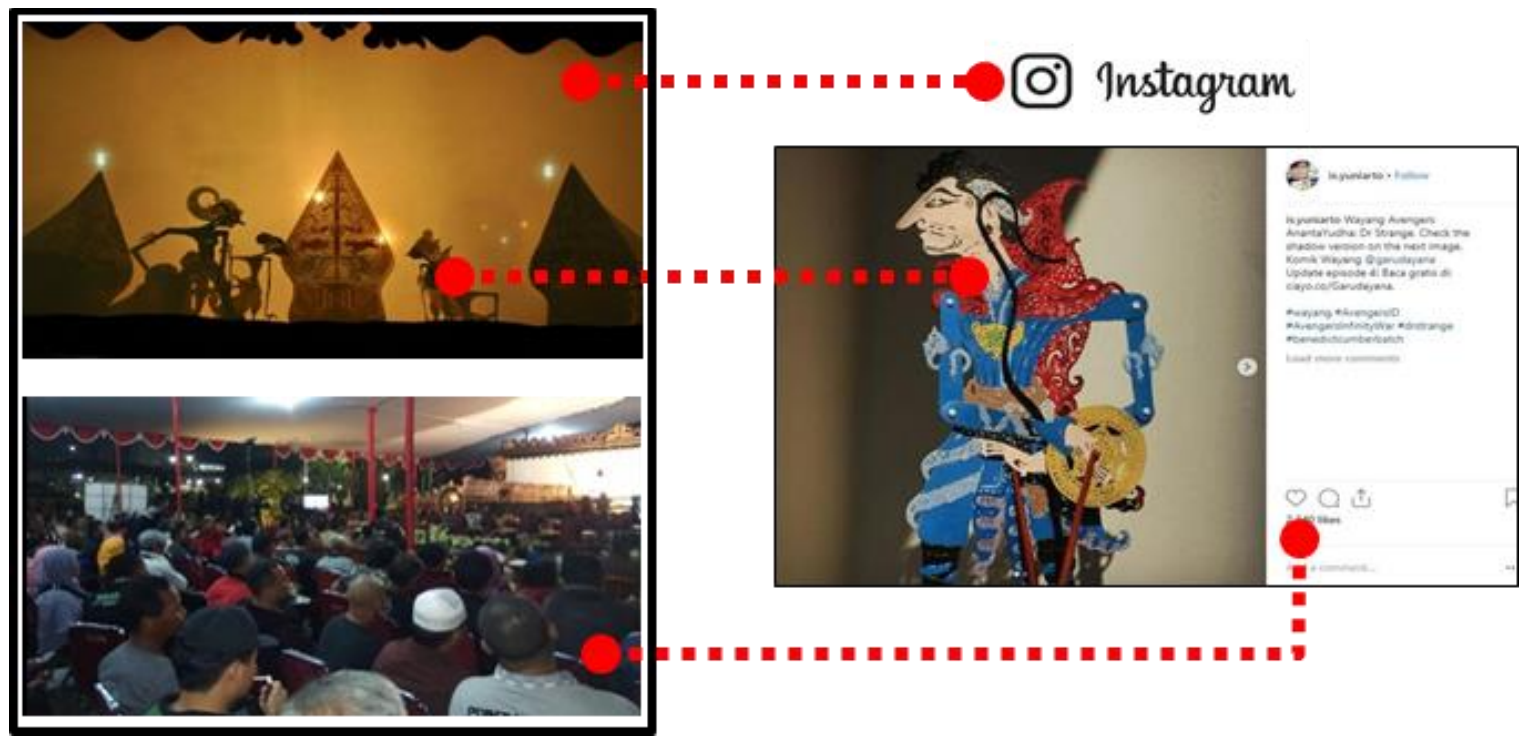

Fig. 8. One of the Transformations to Enjoy Wayang Today

(Modification: Akbar, 2019)

Wayang Avenger is a puppet that adapts a Western superhero (marvel) by applying traditional wayang's visual style. Creation and innovation do not immediately leave traditional art's essence but reinforce a new form (novelty) (Suharson 2019, 21). Ki Djliteng Suparman supported this statement stating that creative wayang is one solution to solve the problems of wayang life today, without leaving its content (interview, 6 Nov 2019). According to Bambang Suwarno, we can no longer interfere with the argument because the wayang purwa has reached its peak of perfection. Therefore, new puppet creations must match the existing wayang, namely the wayang purwa (interview, 6 Nov 2019). So, puppets that develop up to the generation of new wayang creations need to consider still the "red thread" of the wayang's existence not to leave its "roots," namely wayang purwa.

Wayang kulit purwa contains various teachings and ethical values sourced from several types of literature and cultural wisdom. Wayang also prioritizes value as true truth, which occupies a highvalue position. The concept of truth as the true value is evident that all good knights in wayang always try to become "human defenders of truth." Their actions in the wayang drama symbolize their efforts to eliminate evil and even untruth. The values contained in the wayang are essential in human life. The hope is that by experiencing the puppet show, the audience can absorb the values in it and can make it happen in the life of society, nation, and state. Value is the essence, and the soul is the object's substance, where various accidents (properties/aspects) happen to be attached (Sidi Gazalba 1991, $50)$.

Briefly, the Mahabharata tells the story of the conflict between the five Pandavas and their cousins, the Korawa, which numbered one hundred people. The conflict is about a dispute over the land and government rights of the Astina State. The climax was the Bharatayudha war on the Kurusetra field. The battle lasted eighteen days. In Avenger's wayang creations, the puppet characters' visualization is like the characters in the film. The Indonesian traditional wayang stories originating from Mahabharata and Ramayana's epics, as a medium for telling stories about heroism and war, have a story pattern similar to that of the Avengers film.

\section{Conclusion}

The creation of the wayang avenger exists as the existence of its current creator. The introduction of the wayang avenger for the first time was still in the form of design through the Instagram social media account, and the realization became the form of wayang in 2018. Wayang avenger is a form adaptation to suit wayang values in a new aesthetic idea. This puppet is a medium for presenting the 
concept of values in protecting others, fighting crime and all its effects, and teaching teamwork as the main point. Therefore, the wayang avenger themes are relatively similar to those in wayang kulit purwa, namely character education for personality enhancement. One of the main themes in wayang kulit purwa is heroism, which is parallel to superhero heroism as a basic moral expression in wayang avenger.

On the visual side, the concept of vehicle transfer is the main reference to transform the adjustment of visual elements. Tatahan and sunggingan play an important role in shaping the appearance and attributes of the puppets. Combining two cultural products into one visual composition contains hope to make it easier for the younger generation to live up to cultural values and wayang beauty. The wayang avenger's contemporary format is a bridge for the younger generation to get closer to the traditional wayang kulit purwa.

\section{Reference}

Acu, Adrian. 2016. "Time to Work for a Living: The Marvel Cinematic Universe and the Organized Superhero." Journal of Popular Film and Television 44 (4): 195-205. https://doi.org/10.1080/01956051.2016.1174666.

Bangsa, Buku Antar. 2002. Indonesian Heritage. Jakarta: Published by Buku Antar Bangsa for Grolier International.

Boonstra, Sadiah. 2019. "Putting on a Show; Collecting, Exhibiting and Performing Wayang at the Tropenmuseum from Colonial Times until the Present.” Wacana 20 (1): 118. https://doi.org/10.17510/wacana.v20i1.730.

Byard-Jones, Tim. 2001. "Developments in Performance Practice, the Creation of New Genres and Social Transformations in Yogyakarta Wayang Kulit." Contemporary Theatre Review 11 (1): 43-54. https://doi.org/10.1080/10486800108568609.

Cohen, Matthew Isaac. 2007. "Contemporary Wayang in Global Contexts." Asian Theatre Journal 24 (2): 338-69. https://doi.org/10.1353/atj.2007.0032.

Damono, Sapardi Djoko. 2018. Alih Wahana. Jakarta: PT Gramedia Pustaka Utama.

Feldman, Edmund Burke. 1991. Art as Image and Idea Atau Seni Sebagai Wujud Dan Gagasan. Edited by Sp. Gustami. Terjemahan. Yogyakarta: Fakultas Seni Rupa dan Desain Institut Seni Yogyakarta.

Ghani, Dahlan Abdul, and Mohd Sidin Bin Ahmad Ishak. 2011. "Preserving Wayang Kulit for Future Generations.” IEEE Multimedia 18 (4): 70-73. https://doi.org/10.1109/MMUL.2011.70.

_ 2012. "Relationship Between The Art of Wayang Kulit and Disney's Twelve Principles of Animation." Revista de Cercetare Si Interventie Sociala 37: 162-79. http://www.rcis.ro/en/section1/48volumul-372012iunie/427-relationship-between-the-art-of-wayang-kulit-and-disneys-twelveprinciples-of-animation.html.

Haryanto, S. 1991. Seni Kriya Wayang Kulit, Sen Rupa Tatahan Dan Sunggingan. Jakarta: PT Temprint.

Koh, Wilson. 2014. “'I Am Iron Man': The Marvel Cinematic Universe and Celeactor Labour.” Celebrity Studies 5 (4): 484-500. https://doi.org/10.1080/19392397.2014.933675.

Lavin, Michael R. 1998. “A Librarian's Guide to Marvel Comics.” Serials Review 24 (2): 47-63. https://doi.org/10.1080/00987913.1998.10764445.

Munandar, Utami. 2002. Kreatifitas Dan Keberbakatan : Strategi Mewujudkan Potensi Kreatif Dan Bakat. Cetakan ke. Jakarta.

Panofsky, Erwin. 1955. Meaning in Visual Art. New York: Doubleday and Company Inc.

Pratama, Dendi. 2015. "Wayang Kreasi: Akulturasi Seni Rupa Dalam Penciptaan Wayang Kreasi Berbasis Realitas Kehidupan Masyarakat.” Deiksis 3 (04): 379-96.

Putra, Muhammad Andika. 2018. "Sentuhan Is Yuniarto: Komik Garudayana Hingga Wayang Avengers." Cnnindonesia.Com. 2018.

Sidi Gazalba. 1991. Sistematika Filsafat, Pengantar Kepada Teori Pengetahuan. Kedua. Jakarta: PT Bulan 


\section{Bintang.}

Soetarno dan Sarwanto. 2010. Wayang Kulit Dan Perkembangannya. Surakarta: ISI Press Solo dan CV. Cendrawasih.

Storey, J. Douglas. 1993. "Mythology, Narrative, and Discourse in Javanese Wayang towards Cross-level Theories for the New Development Paradigm.” Asian Journal of Communication 3 (2): 30-53. https://doi.org/10.1080/01292989309359581.

Suharson, Arif. 2019. “Estetika Dan Etika Wuwungan Rumah Tradisional Jawa Dalam Era Global.” CORAK. https://doi.org/10.24821/corak.v8i2.2794.

Sunarto. 1997. Seni Gatra Wayang Kulit Purwa. Semarang: Dahara Prize.

\section{Biography}

Taufiq Akbar is a Lecturer at the Visual Communication Design Study Program, Faculty of Languages and Arts at University of Indraprasta PGRI Jakarta. He completed his undergraduate education at the Visual Communication Design Study Program, University of Indraprasta PGRI, and master's education in Product Design at Trisakti University Jakarta. His bachelor thesis, entitled "The Design of Plastic Puppets as an Effort to Introduce Wayang Art to the Young Generation," became the starting point for him to dare to make wayang creations of the first times. The second puppet creations he created is Wayang GID (Glow In The Dark), the result of his thesis while studying for his master's degree at Trisakti University Jakarta. He is currently looking at the Postgraduate Program at ISI Surakarta.

Dendi Pratama is a Lecturer and Deputy Dean of the Faculty of Language and Arts at the University of Indraprasta PGRI Jakarta. His main research is traditional arts and wayang kulit. He has completed his doctoral studies at the Indonesian Institute of the Arts in Surakarta with a dissertation entitled "Wanda Figure Gatotkaca in Surakarta Style Purwa Leather Wayang."

Sarwanto is a professor of puppetry at the Indonesian Institute of the Arts, Surakarta. Undergraduate education at the Indonesian Karawitan Academy (ASKI) Surakarta in 1983, Masters Education in the Study Program of Performing Arts and Fine Arts, Postgraduate Education at UGM Yogyakarta in 1999, and Doctoral Education in the Performing Arts and Fine Arts Study Program, Postgraduate at UGM Yogyakarta as well, and earned a Doctorate in 2007. He is a puppeteer and researcher in the field of wayang. As an intellectual, his productivity is very high. The works produced include scientific works and works of art. The art-works that have been made involve manuscripts in wayang, gamelan compositions in traditional forms primarily for the Wayang world's needs. In the last two years, he has produced more than 25 Copyright certificates.

Sunardi was Bachelor's degree in Puppetry Arts at STSI Surakarta in 1995. He received his Masters in the Art Studies Program at STSI Surakarta in 2004. He is a 1661 Doctorate graduate from Gadjah Mada University Yogyakarta, which he obtained in 2012. Currently, he serves as Vice-Rector II and is active in writing scientific works in Wayang Performing Arts. He has produced several papers in research reports, books, journals, and documents on puppet values, wayang plays, puppeteers, wayang janturan, pakeliran sandosa, and art learning models, Wayang and Javanese society, wayang jokes, puppet semiotics, Islam and Wayang, puppet symbolism, and many other studies. 